\title{
Kartlegging av nær døden-opplevelser
}

\author{
Kritisk syke mennesker kan av og til fortelle om intense nær døden-opplevelser. Det foreligger et måle- \\ instrument for å avdekke slike, og det er nå oversatt til norsk. Vi ønsker å gjøre fenomenet og skalaen bedre \\ kjent blant norsk helsepersonell.
}

Greyson-skalaen ble utviklet i USA i 1970årene for å kartlegge såkalte nær dødenopplevelser som mennesker i livstruende situasjoner kan oppleve i bevisstløs tilstand. Skalaen er basert på standardiserte kriterier. Den er nå oversatt til norsk i henhold til anerkjente kriterier for oversettelse av slike instrumenter (1).

Nær døden-opplevelser er definert som dype og universelle sinnstilstander med tydelige karakteristika (2). Internasjonalt har fenomenet vært et økende forskningsfelt siden 1980-årene, og ofte har man tatt i bruk Greyson-skalaen $(3,4)$. I Norge har interessen for feltet manifestert seg gjennom blant annet TV-programmer, avisartikler og en bokutgivelse (5).

Anslagsvis 10-18\% av kritisk syke antas å ha hatt en nær døden-opplevelse, og fenomenet undersøkes ofte i tilknytning til pasienter som har overlevd hjertestans $(2,3)$. Når pasientene våkner, kan de ofte berette om persepsjoner av lys eller lysende skikkelser, de kan ha hatt hørselsopplevelser og forteller at noen har snakket til dem, ofte om moralske og verdirelaterte forhold (2). Noen hevder at opplevelsen ble et vendepunkt $i$ livet og forte til endrede livsverdier og livsvalg. Andre kan oppleve det som vondt og belastende $(3,6,7)$.

En nær døden-opplevelse kan ha religiøs og livssynsmessig betydning (8), og pasienter med besværlige nær døden-opplevelser kan oppleve frustrasjon og bli psykisk traumatisert av hendelsen (7). Innleggelse $\mathrm{i}$ intensivavdeling kan bringe pasienten inn $i$ en prosess der det er vanskelig å forstå det man har vært igjennom, uavhengig om de har hatt slike opplevelser eller ikke $(9,10)$. De som har vært nær døden og hatt en positiv opplevelse, kan oppleve posttraumatisk vekst (11). Kunnskap om slike fenomener kan ha overføringsverdi til andre pasientgrupper enn dem med hjertestans (12).

Kartlegging av nær døden-opplevelser kan være viktig, siden pasientene kan ha behov for samtale og oppfølging i etterkant (13). Å avdekke positive og vekstfremmende nær døden-opplevelser - og også de besværlige - kan gi ny kunnskap som hjelper helsepersonell, sykehusprester og andre samtalepartnere til å møte pasientene på en bedre måte.

\section{Greyson-skalaen}

Denne skalaen er testet for om pasientene underrapporterer eller overrapporterer nær døden-opplevelser (14) og om minnene om opplevelsene endres over tid (15). Målingene er statistisk validert (16).

\section{RAMME 1}

Greyson-skalaen slik den nå foreligger i norsk oversettelse

Hovedspørsmål 1: Virket det som om tiden gikk fortere eller saktere?

1-1: Det virket som om tiden gikk fortere eller saktere enn vanlig.

1-2: Det virket som om alt skjedde samtidig, eller så stoppet tiden eller mistet all betydning.

Hovedspørsmål 2: Gikk tankene dine fortere?

2-1: Fortere enn vanlig.

2-2: Utrolig fort.

Hovedspørsmål 3: Kom hendelser fra fortiden din tilbake til deg?

3-1: Jeg husket mange hendelser fra fortiden.

3-2: Fortiden min kom foran meg i glimt, ute av min kontroll.

Hovedspørsmål 4: Virket det som om du plutselig forsto alt?

4-1: Alt om meg selv eller andre.

4-2: Alt om universet.

Hovedspørsmål 5: Hadde du en følelse av fred eller velbehag?

5-1: Lindring eller ro.

5-2: Utrolig fred eller velbehag.

Hovedspørsmål 6: Hadde du en følelse av glede?

6-1: Lykke.

6-2: Utrolig glede.

Hovedspørsmål 7: Hadde du en følelse av harmoni eller enhet med universet?

7-1: Jeg følte meg ikke lenger i konflikt med naturen.

7-2: Jeg følte meg forent eller ett med verden.

Hovedspørsmål 8: Så du eller følte du deg omsluttet av et strålende lys?

8-1: Et usedvanlig strålende lys.

8-2: Et lys av tydelig mystisk eller utenomjordisk opprinnelse.

Hovedspørsmål 9: Var sansene dine mer livfulle enn vanlig?

9-1: Mer livfulle enn vanlig.

9-2: Utrolig mer livfulle.

Hovedspørsmål 10: Virket det som om du oppfattet ting som skjedde andre steder, som ved oversanselig oppfattelsesevne?

10-1: Ja, men faktaene er ikke blitt sjekket.

10-2: Ja, og faktaene er blitt sjekket.

Hovedspørsmål 11: Kom scener fra fremtiden til deg?

11-1: Scener fra min egen fremtid.

11-2: Scener fra verdens fremtid.

Hovedspørsmål 12: Følte du deg atskilt fra kroppen din?

12-1: Jeg mistet oppfattelsen av kroppen min.

12-2: Jeg forlot tydelig kroppen min og befant meg utenfor den.

Hovedspørsmål 13: Virket det som om du trådte inn i en annen utenomjordisk verden? 13-1: Et fremmed og merkverdig sted.

13-2: En tydelig mystisk eller utenomjordisk verden.

Hovedspørsmål 14: Opplevde du en mystisk skikkelse eller et nærvær eller hørte du en stemme som du ikke kunne kjenne igjen?

14-1: Jeg hørte en stemme jeg ikke kunne kjenne igjen.

14-2: Jeg opplevde en bestemt skikkelse eller hørte en stemme av tydelig mystisk eller utenomjordisk opprinnelse.

Hovedspørsmål 15: Så du åndene til avdøde, eller åndene til religiøse skikkelser? 15-1: Jeg fornemmet at de var der.

15-2: Jeg så dem faktisk.

Hovedspørsmål 16: Kom du til en grense eller et punkt der det ikke var noen vei tilbake? 16-1: Jeg kom frem til en klar og bevisst beslutning om å «vende tilbake» til livet.

16-2: Jeg kom til en sperring jeg ikke hadde tillatelse til å krysse, eller ble «sendt tilbake» mot min vilje. 
Greyson-skalaen er i bruk i nyere studier innenfor bevissthetsforskning og nevrologi $(2,17)$. Den er bygd opp rundt 16 hovedspørsmål der man svarer ja eller nei (16). Ved ja besvares ett av to underspørsmål som er gradert til ett eller to poeng ut fra intensiteten i opplevelsen.

\section{Norsk oversettelse av Greyson-skalaen}

Oversettelse av engelskspråklige instrumenter til et annet språk til bruk i en annen kultur kan være utfordrende. Det anbefales

\section{«Kartlegging av nær døden-opplevelser kan være viktig, siden pasientene kan ha behov for samtale og oppfølging i etterkant»}

derfor at oversettelsesprosedyren dokumenteres nøyaktig (18). Etter avtale med forfatteren av instrumentet, Bruce Greyson, har vi samarbeidet om en norsk oversettelse av skalaen (ramme 1).

Greyson-skalaen ble oversatt i henhold til oversettelsesprotokollen til The World Health Organization Quality of Life Assessment (1), som foreskriver fasene med oversettelse, ekspertgruppe, tilbakeoversettelse og testing av den endelige versjonen. Den ble oversatt til norsk av førsteforfatter og deretter forelagt ekspertgruppen.

Medlemmene i gruppen hadde norsk som morsmål, snakket flytende engelsk og var kjent med terminologien knyttet til spiritualitet og ut-av-kroppen-opplevelser. De hadde kompetanse innen teologi, religionspsykologi og intensivsykepleie. I prosessen deltok også personer med annen medisinsk kompetanse. Det ble enighet om en versjon som ble sendt til to uavhengige oversettere, som så oversatte tilbake til engelsk. Versjonene ble deretter sendt til skalaens forfatter for gjennomlesing. Det bemerkes at den norske oversettelsen er testet i en pilot (data ikke publisert), men at den ikke er blitt validert for norske forhold.

Vi håper at denne artikkelen kan bidra til at pasienter med nær døden-opplevelser kan få tilbud om samtale og oppfølging.

Vi takker Hans-Stifoss Hansen, Helene Berntzen, Lars Danbolt, Jenniffer Kerr, Helge Skulstad og Bruce Greyson for deres viktige bidrag i oversettelsesprosessen. Takk også til Amjad lqbal Hussain for medisinskfaglig veiledning under pilotfasen.

\section{$\emptyset y s t e i n$ Buer \\ oeybue@ous-hf.no \\ Mary Kalfoss \\ Lars Weisæth \\ Bjørn Bendz}

Øystein Buer (f. 1960) har vært sykehusprest ved Oslo universitetssykehus siden 2007. Han er er medlem i sykepleierforskergruppen ved Akuttklinikken samme sted.

Forfatter har fylt ut ICMJE-skjemaet og oppgir ingen interessekonflikter.

Mary Kalfoss (f. 1947) er professor i «public health» ved høyskolen Diakonova.

Forfatter har fylt ut ICMJE-skjemaet og oppgir ingen interessekonflikter.

Lars Weisæth (f. 1941) er professor emeritus dr.med. ved Institutt for klinisk medisin, Universitetet i Oslo. Han har forsket i 42 år på situasjoner som truer eller tar liv.

Forfatter har fylt ut ICMJE-skjemaet og oppgir ingen interessekonflikter.

Bjørn Bendz (f. 1964) er overlege/førsteamanuensis ved Kardiologisk avdeling, Oslo universitetssykehus, Rikshospitalet.

Forfatter har fylt ut ICMJE-skjemaet og oppgir ingen interessekonflikter.

\section{Litteratur}

1. The World Health Organization Quality of Life assessment (WHOQOL): position paper from the World Health Organization. Soc Sci Med 1995; 41 : 1403-9.
2. Facco E, Agrillo C, Greyson B. Epistemological implications of near-death experiences and other non-ordinary mental expressions: Moving beyond the concept of altered state of consciousness. Med Hypotheses 2015: 85: 85-93

3. Parnia S, Spearpoint $K$, de Vos $G$ et al. AWAREAWAreness during REsuscitation-a prospective study. Resuscitation 2014; 85: 1799-805.

4. Lai CF, Kao TW. Wu MS et al. Impact of near-death experiences on dialysis patients: a multicenter collaborative study. Am J Kidney Dis 2007; 50 124-32, 132.e1-2.

5. Alexander E. Himmelen finnes: en nevrokirurgs fascinerende reise inn i døden og tilbake. Oslo: Cappelen Damm, 2013.

6. van Lommel P. Near-death experiences: the experience of the self as real and not as an illusion. Ann N Y Acad Sci 2011; 1234: 19-28.

7. Greyson B, Bush NE. Distressing near-death experiences. Psychiatry 1992; 55: 95-110

8. Wilde DJ, Murray CD. The evolving self: finding meaning in near-death experiences using Interpretative Phenomenological Analysis. Ment Health Relig Cult 2009; 12: 223-39

9. Storli SL. Living with experiences and memories from being in intensive care: a lifeworld perspective. Troms $\varnothing$ : Det medisinske fakultet, Universitetet i Tromsø, 2007.

10. Lee SA, Feudo A, Gibbons JA. Grief among neardeath experiencers: pathways through religion and meaning. Ment Health Relig Cult 2014; 17: 877-85

11. Khanna S, Greyson B. Near-Death Experiences and Posttraumatic Growth. J Nerv Ment Dis 2015; 203: 749-55

12. Charland-Verville V, Jourdan JP. Thonnard M et al. Near-death experiences in non-life-threatening events and coma of different etiologies. Front Hum Neurosci 2014: 8: 203

13. Greyson B. The near-death experience as a focus of clinical attention. J Nerv Ment Dis 1997; 185 327-34.

14. Greyson B. «False positive» claims of near-death experiences and «false negative» denials of neardeath experiences. Death Stud 2005; 29: 145-55.

15. Greyson B. Consistency of near-death experience accounts over two decades: are reports embellished over time? Resuscitation 2007. 73: 407-11.

16. Lange R, Greyson B, Houran J. A Rasch scaling validation of a 'core' near-death experience. Br J Psychol 2004; 95: 161-77.

17. Charland-Verville V, Lugo Z, Jourdan J-P et al. Near-Death Experiences in patients with locked-in syndrome: Not always a blissful journey. Conscious Cogn 2015; 34: 28-32.

18. pilker B. Quality of life and pharmacoeconomics in clinical trials. 2. utg. Philadelphia, PA: Lippincott-Raven, 1996.

Mottatt 8.11. 2016, første revisjon innsendt 16.11. 2016, godkjent 21.11. 2016. Redaktør: Ketil Slagstad.

Publisert først på nett. 